\title{
The Marketing Implications of Value Chain Governance Strategies of Wine Products Using Geographical Indications (GIs) in Italy and UK
}

Raymond Hawkins-Mofokeng, Department of Agricultural Economics and Sciences, University of Bologna, Bologna, Italy

Maurizio Canavari, Department of Agricultural Science, University of Bologna, Bologna, Italy

Martin Hingley, Lincoln International Business School, University of Lincoln, Lincoln, UK

\begin{abstract}
Value chain governance (VCG) strategies have important marketing implications for specific wine and agri-food products that used GIs in Italy and UK. There are many challenges surrounding the prevailing trend or movement towards the adoption of exclusive quality standards and distinctions in the global supply chains of agri-food products, including wines to support the conception of traceability and safety assurances. This article aimed to reviewing previous research that could be relevant to the analysis of governance mechanisms in supply chains related to GIs for these products. The study analyzed how other researchers coped with these research issues. The survey was qualitative in nature, and recapped selected case studies from Italy and UK, regarding the VCG of wine and food products GIs. Therefore, the findings were limited only to the impact of VCG, wine and food production in these areas and could not be generalized beyond them. The article contributes in advancing knowledge and transferring it from existing situations in developed countries or markets to the developing ones.
\end{abstract}

\section{KEYWORDS}

Agri-Food, Geographical Indications (GIs), Italy, Marketing, Strategies, United Kingdom “UK” (England and Wales), Value Chain Governance (VCG), Wines

\section{INTRODUCTION}

Value chain governance (VCG) designs possess vital business suggestions to any stakeholder involved with specific references to the product and industry types, which means that the more people, transactions, interactions, ideas, or activities are involved the more growth and returns are realised; as well as opportunities that arise along the whole value chain spectrum (Humphrey and Schmitz, 2001). However, the undisputed issues that the global value chains of agricultural products cannot ignore in general are traceability and safety assurances. These issues create outstanding challenges that relate to a shift towards the adoption of exclusive quality standards and product distributions, which still need to be addressed (Clement-Lopez et al, 2014).

This movement towards the adoption of exclusive quality standards and product destinations does not, however, fully consider small-scale farmers in global agri-food chains, and also hinders them to access global markets in terms of exports and imports as far as terms and conditions relating to barriers to entry in global trading are concerned (Bitzer, Obi and Ndou, 2016). On the other hand, 
recent evidence shows that, even in some other developed countries that have adopted this notion (of quality standards) within their domestic trading boundaries, they experienced concerns regarding their retailers' requests for unachievable perfection on the production and provision of agri-food products; which results in food wastage along the supply chain (Goldenberg, 2016).

According to Hammervoll (2011), value is created through the establishment of cooperative connections amongst organizations, which offers essential advantages to all partners involved, due to their sharing of expertise, information, and creativity management. However, there is limited knowledge regarding how value formation must be governed. Humphrey and Schmitz (2001), further investigate as to why firms will tend to set and impose restrictions along the chain. It is important to understand how this concept functions and why it matters in the global supply chain spectrum, for example, in order to control and assist in challenges facing the industry in relation to agri-food safety, traceability, food wastage and child labor issues. This may have direct and indirect impact on the value chain, and stakeholders since retailers who control supply chains mostly have no direct possession of production and manufacturing facilities, and rather take ownership only when goods are in their possession (USAID Microlinks, 2016). Lee, Gereffi and Beauvais (2012) maintain that there is a need for the development of adequate agri-food quality standards and destinations in order to adhere to the strict public food regulations, cutting down costs and lowering the degree of uncertainties along these complex supply chains to address such major challenges.

Fung (2013) indicates that supply chains differ when it comes to their distinctiveness, when it comes to facing different tests, and when it comes to needing different operating as well as policy requirements. Nevertheless, their similarity revolves around their reliance on the transmission of intelligence and data through the use of Internet, information and technological advancements. This not only enhances or changes the firm's business models or nature but also advances the characters of typical consumers; who may turn out to be informative and tech-savvy; thanks to the power of information and knowing exactly what they need, how it must be and where to get or out-source it (Cimino and Marcelloni, 2010). Fung (2013) further adds that these technological advancements improve the environment, but turns it into a more complicated one.

Geographical Indications (GIs) are names or symbols used on agricultural products to denote their geographic origins and qualities, and even the reputation associated with those origins. In this case, quality is linked to the authentic geographical place of production. Moreover, GIs have been fostered as powerful devices that enhance value as well as rural economic development (Canavari et al, 2017). Therefore, due to the nature of the problem under study, the governance of GIs is viewed as a significant model that can be used in addressing the issues of traceability and safety, and how value can be created, transferred and distributed along the supply chain (Giovannucci, 2007; and Rosa, 2015). This study is primarily interested in exploring agri-food products and wine and food GIs' marketing opportunities, as a strategic differentiation or branding phenomena, especially for some of these products which have a longer shelf-life, such as wines and cheeses; and the fact that they have already been determined and certified for being of great quality from their production lines or consortia (Giovannucci et al, 2009).

The study also examines how value chain governance functions in terms of policies, control, administration, relationships, trust, power-sharing or relations, and the management of all internal and external activities that occur along the chain (Gereffi, Humphrey and Sturgeon, 2003). Most importantly how the value is created and transferred, which is viewed as an underlying foundation of marketing discipline in this study (Canavari et al, 2017).

Therefore, since food and wine products (GIs) are already of certified quality, this study investigates the most appropriate value chain governance models and structures; how to enhance the conventional ones to serve these products and ultimately benefit everyone in the chain. The paper consists of a 
comparison study between two regions, Italy and the UK (England and Wales). Italy has a long history regarding these products as well as their management, plus it is a major wine producing country, while the UK (specifically England and Wales, as there is no significant wine production in 
other parts of the UK: Scotland and Northern Ireland), which is relative a newcomer in wine production in these modern times. The UK has a very large import market for wine, sourcing globally, but in terms of wine production, though, it is small but specialized. However, the UK enjoys the recent adoption of GIs for wines; which, therefore, makes the two countries interesting and contrasting cases.

The main aim of the study is to review previous research that can be relevant to the analysis of governance mechanisms in supply chains relates to Geographical Indications for wine and food products. Amongst the studies that the researchers are aware of, none have addressed these issues to a comprehensive extent by which conceptual challenges surrounding the prevailing trend or movement in switching towards the adoption of exclusive quality standards and distinctions in the global supply chains of agricultural products, such as wines can be identified and analyzed. Therefore, this study intends to address this problem and to offer new perspectives to the body of the existing knowledge. It will be important to note that, the framework or final report of this study will be intended to provide advice to South Africa (one of the world's leaders in wine production and specialty food products) regarding the concepts behind these matters due to the lack of experience as well as practicality in this regard. Therefore the aim will be fill this gap in some way.

Therefore, this study is organized as follows: it firstly discusses GIs, wine and food products in Italy and the UK (England and Wales), secondly it summarizes theoretical background on value chain governance, thirdly it describes the method and data is used to select the relevant papers, then this is followed by the summary of relevant literature and, finally discussion and conclusions aremade.

\section{THEORETICAL BACKGROUND ON VALUE CHAIN GOVERNANCE (VCG)}

According to Porter (1985), the value chain is a linked set of value-added activities that an organization and its employees carries out to deliver a product from its idea to its ultimate consumers and further, which includes designing, producing, marketing, delivering, supporting products and services, as well as collaborative decision-making processes. So, in accordance to Gereffi and Fernandez-Stark's (2011) clarification, governance simply defines how value chain is controlled, how policies are established, and regular auditing of their appropriate execution, by stakeholders in the supply chain. This includes structures needed to harmonize the powers of the stakeholders in relation to their individual responsibilities, and their basic commitment in reinforcing the welfare and growth of the firm. Moreover, Humphrey and Schmitz (2001), indicate that value chain governance identifies the existing connections between purchasers and traders, service providers and policy makers, who play a huge role in influencing a number of actions needed to develop a product or service that will be delivered to the ultimate consumer. This process is a strategic approach that entails competency and management of all internal and external activities that occurs along the chain; and which contributes positively to the overall success of the company. This theoretical background of value chain governance is organized as follows: why VCG mattered to the stakeholders, types of VCG, determinants of governance structure, and recommended practices.

\section{Why VCG Mattered to Stakeholders}

It is essential to understand the importance of governance to the stakeholders, as these following factors demonstrate how it helped in determining the:

\section{- Acquisition of production capacity}

In a combined entity of a supply chain, it is down to the lead firm's administrative capabilities to ensure that cost reduction, quality improvements and raising the pace of activities are taken care of in order to enhance the arrangements, production streams and boosting expertise, so as to create value (Humphrey and Schmitz, 2001). This is undertaken constantly by assessing and tracking any 
possible discrepancies along the supply chain that can impede the flow of activities and services, for the sake of delivering the right quality of products at the right time. It is also very important to transfer information as well as support to the relevant bodies along the chain by observing what buyers are doing then communicate best practices to deliver services or bring firsthand input on how to advance manufacturing mechanisms together with manufacturer's expertise (USAID Microlinks, 2016). These generic strategies ultimately assist firms in their market access, performance and expansion.

\section{- Market access}

Developed countries have devised mechanisms in order to control the challenges surrounding the trade barriers, which then regulate barriers to entry for developing countries as far as gaining access to the market is concerned since the chain's administration is subjected to a handful of powerful lead firms. Therefore, for firms which are interested in the export production or trading in developed countries needed to contact these lead firms for the permission as well as getting an insight about terms and conditions of gaining access in the new business world.

\section{- $\quad$ Distribution of gain}

According to Humphrey and Schmitz (2001), a clear interpretation of how a value chain is administered set a fair sense of how the distribution of gains occurs along the supply chain. And, Banga (2013), further notes that gains are unevenly distributed across value chains, which means it will be very important for firms to recognize which activities can maximize returns, together with identifying who will be responsible for engaging in these value-adding segments.

\section{- Leverage for policy initiatives}

According to Barnes, Bassot and Chant (2011), when it comes to leverage, policy initiatives are useful tools that can speed up a robust change in the business world which can ultimately affect and influence the way the supply chains, as well as suppliers, operate or approach business. Therefore, grasping the concept behind the chain administration phenomenon and the diversity of authority clearly, lead firms can be able to be in position to aid in terms of control management in any situation across any platform for the benefit of all entities in the bigger picture, adding a progressive value in all avenues or an increase in a reasonable distribution of gains.

\section{Types of VCG}

A further aspect of consideration for this review is to investigate how and where the value is created, transferred and distributed along the supply chain. It is important to understand how value chain governance functions or operates, by evaluating value chain types and comparing them in terms of their structures. Gellynck and Molnar (2009) indicate that value chain governance types differ when it comes to complicated formations of their structures. As such, this approach will open up a wide array of activities along the value chain, which will show how a product is brought to life, its architecture, the involvement of suppliers and their raw materials, its commerce, its transportation and end-users approvals. Therefore, the types of value chain governance explored are in a form of or represent network-style governance, which dwell upon control and coordination of production without having any straightforward possession of any firm, and these types will be illustrated in Figure 1 and defined as follows (Gereffi, Humphrey and Sturgeon, 2003): 


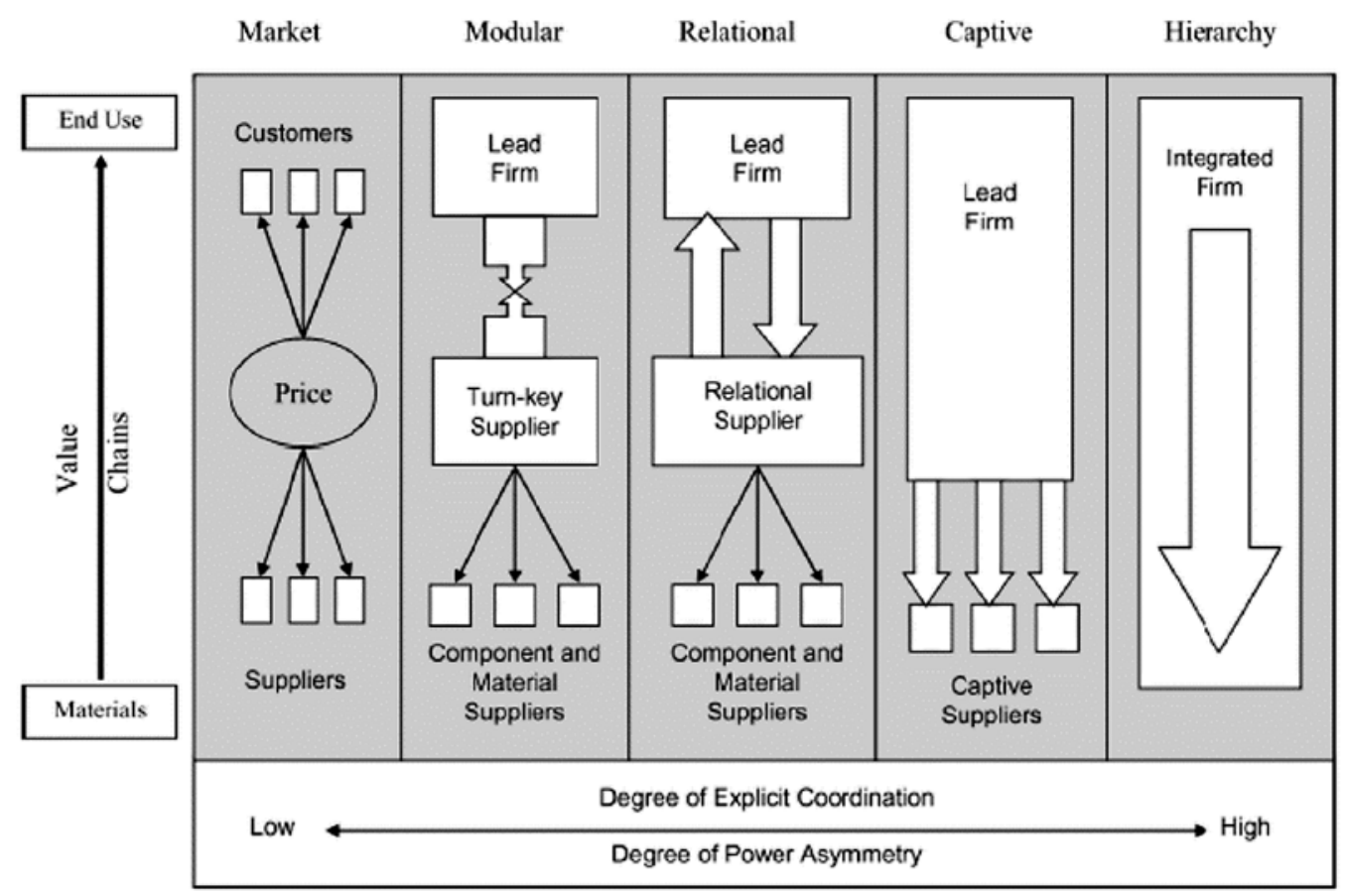

Source: Gereffi, Humphrey and Sturgeon, 2003

These kinds of value chains are characterized by being of arms' length in nature regarding or in insinuating the relationships that exist between stakeholders and are appropriate in merchandising situations. They also entail some simple business dealings, providing necessary instructions or information that is related to how specified a product is or how the product operates, and there is normally less production input involved from buyers. And thus, regional value chains are mostly designed to serve regional market channels (Gereffi, Humphrey and Sturgeon, 2005).

\section{- Modular}

According to Gereffi, Humphrey and Sturgeon (2003), modular value chains represent situations whereby suppliers manufacture products according to the client's specifications and details. And also suppliers take a complete responsibility of simplifying all technical processes related to complicated transactions on behalf of the client.

\section{- Relational}

Relational value chains represent the types of governances that have network structures in terms of design, by which there is synergy amongst buyers and sellers, which further aids in the sharing of information and responsibilities to a larger extent (Menkhoff, 1992). 
Characterized by tremendous standards of auditing as well as regulations from the lead firms, these styles of value chains governance are dominated by few but influential buyers who possess a great deal of power and control over dependent smaller and lesser capable suppliers. And these suppliers require a high level of support (Gereffi, Humphrey and Sturgeon, 2005).

\section{- Hierarchy}

Being the entire operations of a vertically assimilated and managerial control of certain firms that conduct their development as well as production in-house, and these characterize these types of chains due to production specialization with no top-notch suppliers available (Gereffi, Humphrey and Sturgeon, 2003).

\section{Determinants of Value Chain Governance Structure}

Governance structures are never constant in operations, they fluctuate as the industries emerge and expand changing from one level of the chain to the next one (Balwin and Clark, 2000). Therefore, this vigorous character of value chain governance can be determined or influenced by information complexity, information codification and supplier capability, which are discussed as follows and it is also very important to note that if any of these three determinants changes then that affects the governance's arrangements, which may have shifted in an unexpected manner:

\section{- Information complexity}

This is a vital and an influential exchange of information as well as understanding, which ensures that a precise undertaking may transpire. And these types of complex undertakings may be affiliated with either modular, relational or captive governance network-styles; or even hierarchy if they only occur within a single firm (Gereffi, Humphrey and Sturgeon, 2005).

\section{- Information codification}

This is whereby the advancement in industries or business world has figured out, a simpler way of coding complicated information in such a manner that data can be handed or transferred between stakeholders or partners along the supply chain in simpler terms through the state-of-the-art information technology at minimal cost. Trienekens (2011) further emphasizes that industries must invest more into research and development $(R \& D)$ in the field of technological innovations in order to stay ahead and above their competitors.

\section{- Supplier capability}

The supplier must be competent enough to meet the needs his/her business deals in order to be able to offer products of good quality and quantity according to deals requirements at the right time. The supplier must also take good care of the environment in this regard, and to ensure that labor and safety standards are met and kept all the time (Gereffi, Humphrey and Sturgeon, 2005).

A typical illustration to exemplify the idea behind the determinants of value chain governance structure (information complexity, information codification and supplier capability) is that of the computer based system found in grocery stores or supermarkets, namely barcode technology or barcode scanners. These are characterized by black and white zebra-like stripes attached to the products containers. These stripes are coded with precise information regarding the product and can be read by a barcode scanner in specified places in the store (Woodford, 2015). The motive being to help track of products, prices and stock levels, keep track of stolen items, and this allows the keeping of an 
integrated record or data on computer system, which ultimately helps every stakeholder along the chain to have easy access to information about these products, anywhere as long one is part of the chain.

\section{Recommended Practices}

In order to understand and follow proper practices, and investigation regarding the value chain governance has to be conducted to determine, the principles of where, how, as well as when can stakeholders mediate to influence the fundamental changes in business management, by briefly understanding the following dynamics:

\section{- Economic interests}

It is very important to assess the financial performance at any point along the value chain, in order to determine the impact and the degree of changes occurring along it, which may influence the projection of benefits, profit and power that may be received by the lead firms as opposed to suppliers (Megento, 2010).

\section{- $\quad$ Social structure}

This will be a strategic marketing communication mix approach of a firm whereby practitioners collaborate on free or indirect business ventures or involvement with the social or public figures insinuating the caring impression. These public figures can include community leaders, major farmers, and elders, who may want to associate themselves with the firm and end up buying from it (Gereffi, Humphrey and Sturgeon, 2005).

\section{- Competition and strategy}

The firm's competitive edge over its rivals depends on changes in the level of competition, it's positioning in terms of differentiation and innovation or changes in value chain's system, which may determine its profitability in the industry eventually, it is through a successful governance strategy to ensure expediency and longevity (Gereffi, Humphrey and Sturgeon, 2005).

A typical example of proper practices regarding value chain governance is the European Retail Round Table (2016) initiative, whereby; supermarkets or retail stores carry loads of diverse range of products from various companies with peculiar supply chains of unique tendencies as well as ramifications. This forms a network of significant actors who are working together in business partnerships to serve some highly competitive markets, in well-organized operations along their supply chains in order to provide the finest and greatest contemporary offerings to their end-users.

Therefore, lead firms may encourage capacity improving governance amongst all levels of the chain, as well as speeding the development of supporting markets.

The bottom-line is that value chain governance foster information sharing that will lead to creativity which will further help institutions to boost their performance, identity and maintain their competitive edge along the chains. Therefore understanding how the incorporation of highly valuable quality products, such as GIs (Protected of Origin or PDOs) in the supply chain will really work. The idea being that wine and food products GIs as quality certified products can address the issues relative to traceability as well as safety assurance, even adding marginal value to business along the chain hence their exploration in Italy and the UK (England and Wales). 


\section{GIS, WINE, AND FOOD PRODUCTS IN ITALY AND IN THE UK (ENGLAND AND WALES)}

Geographical Indications (GIs), are defined as names or distinctive signs that classify a good as emanating from a demarcated region or domain where a distinguished quality, stature or other unique factors of a good are substantially derived from its geographical roots, human or natural factors there (Giovannucci et al, 2009). Addor and Grazioli (2002) further indicate that, if GIs are used in a proper manner under a well-managed protection, they can become marketing engines of great economic value since they can bring competitive advantage, more added value to a product, increased export opportunities, strengthened brand plus they can protect or help established goods against fraud. Furthermore, GIs as another type of PDOs, where public certifications which represent an offering from a consortium assuring and guaranteeing genuine or authentic quality products to the consumers, which is enforced by different production mechanisms and governance over the supply chain. These signs also helped farmers' or firms' products to gain profitability and global competitiveness in this rapidly evolving industry (Agostino and Trivieri, 2014). A typical GI supply chain involves stakeholders, product, area, specifications and governance.

Italy: Wine and food products play an essential part in the Italian culture and cuisines, and evidence can be seen in retail stores that carry an array of varieties of wines and foods in different price ranges, making affordability suitable for anyone. Italian wines are described as having a very smooth style, aromas as well as flavors, most importantly they are not 'attention seeking' (Oronzo and Partners, 2013). This is made possible by a favorable Mediterranean climate, which makes the country to produce approximately 51.5 million hectoliters $(\mathrm{hL})$ of wines per year, on privately owned or shared vineyards (Oronzo and Partners, 2013).

Recently studies indicate this country to be the number one leading country in wine production and some of the specialty products such as cheeses (GI differentiated ones) in the world interms of volumes, as well as in the consumption of its own wines (OIV, 2016). However, the biggest consumer of Italian wines is the United States, which imported 1.3 billion Euros worth in 2015. While in 2013 companies such as Parmigiano Reggiano (cheese) exported $+5 \%$, and still maintains a steady domestic consumption. According to Stasi et al (2011), the most well-known GIs in the Italian wine market (hotels, restaurants, households and catering) and industry are the ones illustrated in Table 1: These above-mentioned quality certifications, labels, marks or systems associate agricultural products' quality such as wines or cheeses to their territory of origin together with their unique production processes, which symbolize their heritage in terms traditions. These marks make Italian

Table 1. Quality assurance labels

\begin{tabular}{|l|l|l|}
\hline \multicolumn{1}{|c|}{ GIs } & \multicolumn{1}{|c|}{ Full GI name in Italian } & \multicolumn{1}{c|}{ Full GI name in English } \\
\hline DOC (Italian legislation) & $\begin{array}{l}\text { Denominazione di Origine } \\
\text { Controllata }\end{array}$ & The Controlled Designation of Origin \\
\hline DOCG (Italian legislation) & $\begin{array}{l}\text { Denominazione di Origine } \\
\text { Controllata e Garantita }\end{array}$ & $\begin{array}{l}\text { The Controlled and Guaranteed } \\
\text { Designation of Origin }\end{array}$ \\
\hline IGT (Italian legislation) & Indicazione Geografica Tipica & The Geographic Typical Indication \\
\hline DOP/PDO (EU legislation) & $\begin{array}{l}\text { Denominazione di Origine Protetta } \\
\text { (DOP) }\end{array}$ & $\begin{array}{l}\text { Protected Designation of Origin } \\
\text { (PDO) }\end{array}$ \\
\hline IGP/PGI (EU legislation) & Indicazione Geografica Protetta (IGP) & $\begin{array}{l}\text { Protected Geographical Indication } \\
\text { (PGI) }\end{array}$ \\
\hline
\end{tabular}

Table 1: Source (Authors) 
wine or other specialty products to stand out in the market as of good quality. Moreover, the first three marks (DOC, DOCG and IGT) in Table 1 initially are certifications of wine products or spirits only, while the latter (DOP/PDO and IGP/PGI) strictly represent agricultural foodstuff however, there was a mandatory conversion of these two groups of certifications, which transpired in them being applicable for both wines/spirits and food stuff. According to the 2013 Italian wine's industry report, there are 330 DOCs, approximately 70 DOCGs and about 120 IGTs, coming from 2000 indigenous grape varieties. Another study conducted by Gellynck and Molnar (2009) on chain governance structures, indicates that the Italian traditional food and beverage sectors are expected to elevate to higher levels of association as a result of continuous integration within the European Union (EU).

UK (England and Wales): The UK in general is a new player in wine production, but with great economic power and its consumers have a high buying power (Hawksworth and Chan, 2015). However, its wines were literally regarded as some of the worst in the world in terms of taste, perhaps due to the impact of climatic conditions and few producers, which make the British to rely on imported grape concentrates from other countries and even in the past cheap Sherries from Spain and South Africa. However, localized regions within England and Wales have more latterly proven their ability to produce high quality in wines (such as sparkling, like champagne). The volumes are small are specialized and have recently adopted the use of GIs (Robinson, 2016). Smithers (2015), indicates that English wines have changed from being a mockery to gaining respect with the current annual sales of 6 million bottles, and the figure is projected to double up in the year 2020, thanks to family-owned producers such as the Ridgeview Vineyards. This has also inspired new and more developments of vineyards in the UK (England and Wales), amounting to $40 \%$ of them in 2013. UK wine producers use PDO or PGI systems, the same protection schemes that are used by the Italian wine and food products. These schemes are applied to both wines and spirits as well. Thesparkling wines amounted to 1 billion Pounds Sterling worth of sales in 2016. However, according to Siddle (2015), UK consumers are paying nearly $60 \%$ in tax on every bottle of wine as well as $80 \%$ on spirits, which questions the system's balance when it comes to the payment of duty rates, and this country is the third $\left(3^{\text {rd }}\right)$ largest importer of Italian wines in the world in 2015.

According to Unknown (2016), wine consumption in the United Kingdom is gradually growing since the most dominating alcoholic beverage is beer, which placed it in the second place nationwide. In addition, as far as trends are concerned, in UK's wine industry, young consumers are the largest users of wine products but this was projected to change in the future due to the fact that they have shown a great tendency of switching liquor from time to time, which may imply that their behavior is most influenced by fads, therefore, successful efforts strictly rely on marketers (Ritchie, 2011). This could be possible through the use of branding, which can help in terms of product identity, plus there can be an increasing growth of private labels (e.g. Fairtrade) that are not only gaining premiums as well as segments and drive poorer brands out of business. When it comes to the food supply chain, the UK industry is more conscious about the visibility of the food supply chains, sustaining an increased level of available food, waste reduction and satisfying consumer's needs with the right quality food products or even services, and working endlessly towards adjustment measures where need will be along the chain to ensure that all is possible (Siddle, 2015). Schmitz (2001), further emphasizes this notion, that in countries such as the UK, there are quality systems in place in their major supermarkets that exercise control over food supply chains in order to ensure good inter-firm relationships along the value chain.

In the European wine and food industry, producers from countries such as Italy possess a great competitive edge due to certifications, when it comes to quality over other wine products, from where producers are not the members of a relevant consortium; from the PDO system's frame of reference. According to Agostino and Trivieri (2014), quality wine and food products produced in particular areas of Italy are associated with higher exports value due to the GIs. In general, analyzing the relationships between business and quality, meaning the associations between trade and GIs help 
wine consumers not to experience any difficulties at the time of purchase. 


\section{VCG OF WINE AND FOOD PRODUCTS}

According to Wittwer, Berger and Anderson (2003), the global wine industry is a vulnerable business venture that is subjected to consumption fluctuations and shifting purchase patterns, which ultimately affect the production capacities of producers; which subsequently enforce major adjustments along the chain as far as governance is concerned. Whereas, the general food industry as complicated as it may be, is subjected to the international network of various firms that provide most of the food worldwide, apart from subsistence farmers who produce food for their own consumption and can only sell their surplus (Vincent, McLeish and Soemali, 2014).

This idea of shifts in consumption patterns directs some of the European countries to engage in policy changes and different models that emphasize differentiation between premium and non-premium grapes, as well as wines by the region of origin. Diet and health concerns in the EU have led to the development of functional foods, such as the wines produced from grapes, in which the resveratrol (a chemical compound called trihydroxy that is found in some plants, fruits, seeds, and grape-derived products such as red wine, and has been linked to a reduced risk of coronary disease and cancer) content has been enhanced (Barreiro-Hurle, Colombo and Cantos-Villar, 2008). In addition, Gellynck and Molnar's (2009) study on chain governance structures, quote Williamson's (1991) philosophy that outlines that, "the interaction between product and country-specific characteristics, shaped the governance structure” (meaning this gradually determines the structure or shape of governance as in how things operate). On a contrary, Skilton and Wu (2013), argue that although the effectiveness of Geographical Indications may be associated with some marketing activities, which fully rely and depended more on the structures of the governance systems to happen. The reality is that not all governance structures are evenly appropriate for all chains, so all rely upon their specifics to fit in and they also depend on chain members to make suitable choices, and the number of retailers available (Gellynck and Molnar, 2009).

Moreover, a wine and specialty food products' value is strongly linked to the territorial location of its production, by which its competitive advantage in the supply chain rely on the collaborative efforts of its reputation and known information that ease the consumers' decision-making process at the time of purchase, as well as generating profits (Bramley, Bienabe and Kirsten, 2007). Furthermore, these kinds of chains are critically conscious about meeting customers' needs and wants, further respecting the environment in which all operations took place (Fearne, 2009). In general, the supply chain of wine is considered to be one of the most complicated supply chains, which comprises of the following life-cycle stages as indicated in Table 2 (Petti et al, 2006).

These stages can be carried out and combined in many different ways, according to the type of value chain governance adopted in a specific context.

Table 2. Wine Supply Chain

\begin{tabular}{|c|l|l|}
\hline Stages & \multicolumn{1}{|c|}{ Operations } & \multicolumn{1}{c|}{ Activities } \\
\hline 1 & Grape Production & $\begin{array}{l}\text { Pruning, tillage, pest control activities, harvest, transport for field workers \& } \\
\text { products. }\end{array}$ \\
\hline 2 & Wine Production & Stemming and crushing, the fermentation and storage. \\
\hline 3 & Packaging & $\begin{array}{l}\text { Bottle filling, corking, capsuling, labeling, box filling and placement on } \\
\text { pallets. }\end{array}$ \\
\hline 4 & Distribution & Transport-related: local, regional, national or International level. \\
\hline 5 & Consumer Phase & Storage or refrigeration if needed. \\
\hline
\end{tabular}


Table 2: Source: Information drawn from (Petti et al, 2006) 
While on the other hand, the food supply chains such as the one demonstrated in Figure 2 below, emphasize the coordinated industry approach that focus and considers economic factors (internal and external) together with sustainable factors (social and environmental) These are more concerned about the efficient use of resources, reducing emissions, and sustaining the production of good quality products that lessen waste, changing the way conventional supply chains operate and caring about the ultimate consumers (Vincent, McLeish and Soemali, 2014)

Figure 2 outlines an adequate sample of coordinated supply chains, where actors are active and consciously responsible for their activities (management, differentiation, hygiene, training and being informative) in the overall business goals as well as respecting and managing the environment with the use of its resources. Also having the right technological measures to facilitate and improve the existing supply chains, and how this can contribute towards resolving world hunger together with poor nutrition (Vincent, McLeish and Soemali, 2014).

\section{RESEARCH OBJECTIVES}

The researchers' aims were as follows in approaching this study:

- Main Objective: To review previous research that can be relevant for the analysis of governance mechanisms in supply chains that relates to GIs for wine and food products in Italy and the UK (England and Wales). The study uses the following sub-objectives to screen and identify few relevant case studies or literature pertaining the value chains of wine and food GIs in these two countries:

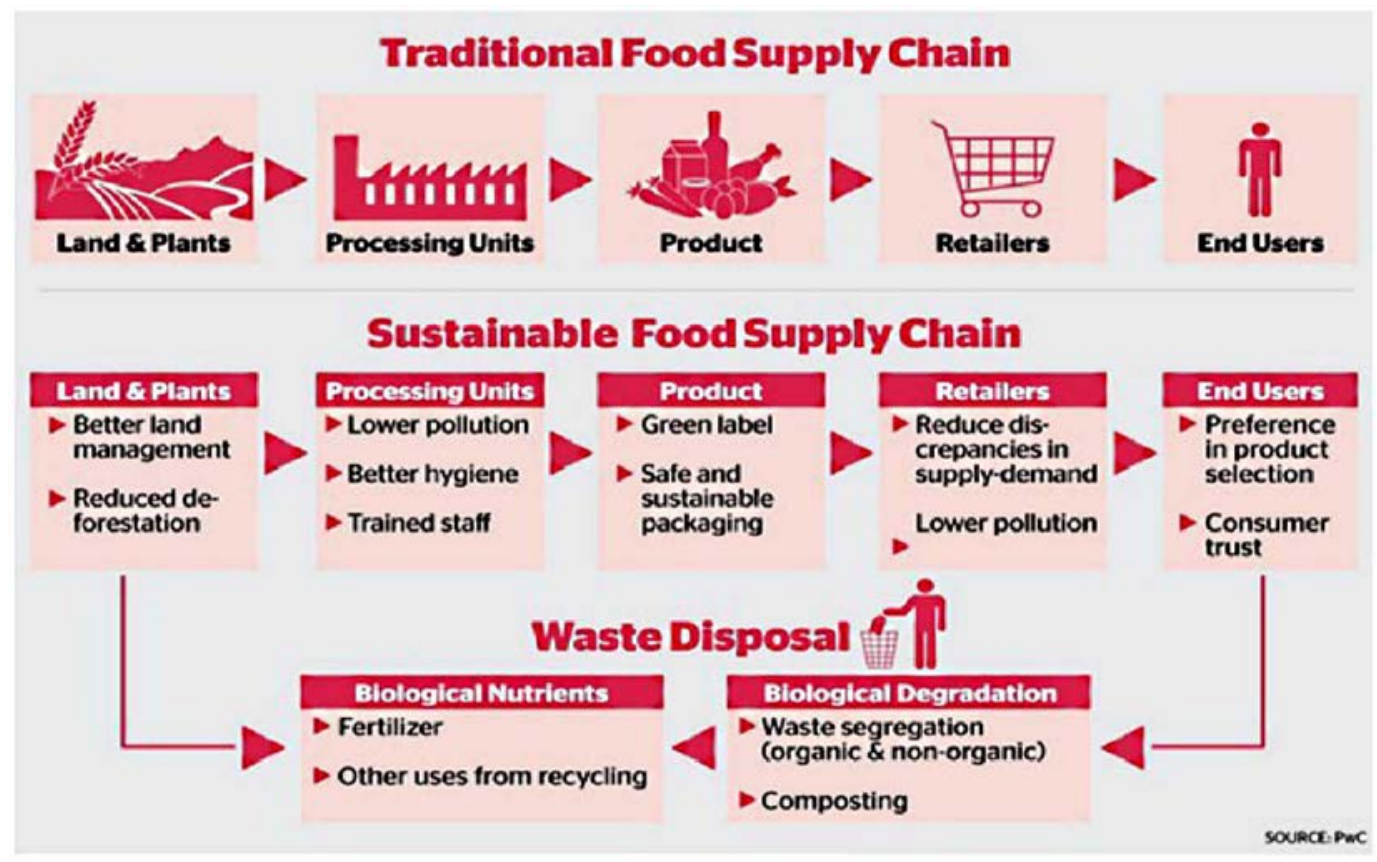


- Sub-Objective 1: To determine whether the literature reports evidence that Geographical Indications can be useful tools for small-scale farmers to gain access to the bigger industry through the use of conventional value chains.

- Sub-Objective 2: To highlight previous analyses on the governance structures and mechanisms in situations where Geographical Indications are working.

- Sub-Objective 3: To explore previous research determining how value chain governance works in terms of relationships, operations, power, rights, decision-making, value creation, transfer and distribution along the chain.

- Sub-Objective 4: To check whether previous analyses determine ways to avoid bottleneck situations along the supply chain, as part of value chain governance.

\section{METHOD AND DATA}

The methodology for this literature review is based on relevant theories that use and involve qualitative research together with the case studies. So, the main aim of this study is to review previous research that can be relevant for the analysis of governance mechanisms in supply chains that relates to Geographical Indications for wine products. The notion is to use the objectives above as a screening procedure to identify relevant case studies or literature relative to the study's aim, specifically in Italy and United Kingdom.

Inspired by the works of Moser, Raffaelli and Thilmany-McFadden, the study adopts a desk research approach since it can only rely on secondary data, whereby it screens these data on the basis of eight (8) keywords, which are derived from the titlenamely:

- Marketing

- Value chain governance (VCG)

- Strategies

- Wines and food products

- Geographical Indications (GIs)

- Italy (IT)

- The United Kingdom "UK"

These Keywords are used to search and retrieve literature from three (3) databases, and those are:

- Scopus

- Google Scholar

- Emerald Insight

Therefore, the researchers further rely on reading relevant abstracts of many studies they come across in order to identify and classify a total number of thirty-three (33) papers, of which are ultimately grouped according to the objectives mentioned earlier on. Researchers are more peculiar about the time periods of these studies, that is, they consider studies that were published in the year 2000 to 2015 appropriate for the nature of our study, and more recent were like a bonus or additional advantage in helping them to draw closure on how the field has been emerging so far (Yin, 2014). It is important to analyze how other researchers who studied topics of their interests or relative to their research coped with these problems or issues; as a result, they further identified and analyzed theirmethods. 


\section{SUMMARY OF THE RELEVANT LITERATURE}

The main aim of this study is to review previous research that can be relevant for the analysis of governance mechanisms in supply chains that relates to Geographical Indications for wine products. The notion is to use these objectives as a screening procedure to identify relevant case studies or literature relative to the study's aim, in Italy, the United Kingdom and neighboring developed markets. Therefore, researchers compile a brief summary of these relevant case studies according to these objectives in this manner since this is a desk study.

\section{Sub-objective 1. Geographical Indications (GIs) as Useful Tools}

Geographical Indications (GIs) have turn to become valuable Intellectual Property rights as “powerful tools” for rural economic development and wealth formulation, which are not up until now being utilized to an optimum level in all countries, particularly in emerging markets as well as in Europe, such as a longevity that Italy has been enjoying regarding these mechanisms, not forgetting their adoption in England and Wales (Idris, 2003 and; Canavari et al., 2017). This has encouraged the European Union (EU) to position itself around the favorable opportunities or potential that GIs possess in protecting local Agrifood cultures, offering a quality pledge to consumers, as well as catering beneficial circumstances for value enhancement in agriculture (Bowen, 2010). Nevertheless, some studies point out that, the prevailing issues around the registration proceedings for GIs still continue to be time-consuming, intricate and too expensive to start as well as to run a GI (Skuras and Vakrou, 2002; and Rangnekar, 2004).

In addition to the concerns regarding costs, questions relating to several factors including market penetration, the economics of launching products, the multiplicity of labels and diverse ideas of quality, together with the alarming existence of alternative and identical products has been identified. In a study conducted on Greek consumers (Skuras and Vakrou, 2002), the findings show that the willingness to pay (WTP), for an origin labelled wine differ according to social and demographic factors, and they can always opt and pay more for an alternative table wine as long as it guarantees the place of origin. Although this has been the case, Rangnekar (2004), further suggested that more measures, focus and remedies have to be put in place in the new arrangements of organizations, manufacturers, wholesalers, dealers and end-users, which will look for protecting particular niche segments, in order to overcome the two problems of market penetration and threats from alternativeproducts.

In general, literature still emphasizes that Geographical Indications serve as strong differentiation strategies that signal quality to consumers, which contribute towards their global competitiveness (Skuras and Vakrou, 2002). However, they cannot achieve this alone in meeting this strategic competitive edge without the incorporation of other marketing mechanisms (Stasi et al, 2011; Rocchi and Gabbai, 2013; and Agostino and Trivieri, 2014). With regards, to differentiation, there is no practical proof related to the effectiveness of the distinction of GIs, in the wine market when it comes to consumers' responsiveness to the price of GIs in the wine market compared to other conventional products. Even though some global markets perceive wine and food GIs products as associated with value premiums, which can make EU wine and specialty food producers gain higher margins on these markets and expand their exports to new markets. Therefore, producers must be aiming at quality as well as diversification granting higher prices. According to Tocco, Carmen and Gorton (2015), even though successful GIs in both Italy and France add value to consortium members and important trading networks, there are restraints in simulating the supply chain model due to weaker domestic buying power and limited consumer awareness of EU quality schemes. In addition, the EU can be affected by its exposure to the trade barriers, as a major international shareholder, however, that is subjected to how barriers to entry are managed (Battaglene, 2011). Nevertheless, it has been noted that these rapidly growing new wine and specialty food importers are highly protected by tariffs and are developing wine and food market regulations, which can prove to be non-tariff barriers (ICE, 2010). 


\section{Sub-objective 2. Gls Governance Structures and Mechanisms}

According to the USAID Microlinks (2016), the fundamental principles of the type of governance pattern are determined by information complexity, information codification and supplier capability, which differentiate them among industries. Moreover, the preferable or suitable governance structures (market, modular, relational, captive and hierarchy) are also determined by quality strategies, which include design, product, market, delivery and collaborative decision-making processes. These are supported by agents along the supply chain by which eventually affect the effectiveness of marketing schemes associated with Protected Geographical Indicators (PGIs) and market access (Bowen, 2010; and Skilton and $\mathrm{Wu}, 2013)$. So, this will require innovative approaches, whereby there must be a coordination of knowledge distribution amongst various firms, with the help of technological infrastructures to facilitate modernized processes of governance mechanisms to create and sustain interdependence across other scattered entities to deliver according to expectations as far as their distribution of gains is concerned (Consoli and Patrucco, 2007). For instance, when it comes to distribution strategies, research findings recommend that GI producers through their respective consortia, which oversee their administration, will have to endorse different distribution channels in different countries, as different markets have different dynamics. Particularly, by selling GI wine and food products through retailers and supermarkets in countries that have a high number of supply chains (example, United Kingdom) and using local markets, direct selling or direct marketing and specialized channels in GI products prevail (examples, Italy and parts of France) (Rangnekar, 2004; Rocchi, and Gabbai, 2013; and Tocco, Carmen and Gorton; 2015).

On the issue of GIs consortia, these are organization bodies that govern, protect, promote, build the reputation, provide correct information to the end-users, as well as safeguard the GIs (Rosati, 2015). Although it is time-consuming and expensive to start and run a GI, the economic gains in terms of shared investment among members are subjective to each member and depend on fixed price of a product based on market conditions, demand and supply, product type, transport as well as packaging. Rosati (2015) further indicates that the payments are made with steady monthly interests on the basis of sampling, of which the remainder will be received when the year ended.

According to Rangnekar (2004), the challenges faced by Geographical Indications as far a value chain governance is concerned are related to the process of reorganization of and developing the governance institutions for, GI supply chains in terms of distribution of economic returns and trust. Therefore, in some studies, it is suggested that most organizational and governance challenges need resolutions to attain a smooth synergy in working within and across the supply chain, through a fair equity between cooperation and competition (Raynaud, 2002; and Rangnekar, 2004). The fair equity between cooperation and competition points out a vital need for an independent and representative body to mediate between firms and consider a relational approach of value chain governance. And, as for the origin labeled products, there is a lot of work needed in the supply chain to encourage stakeholders to adapt their current commercial relationships and distribution channels (Albisu, 2002). Furthermore, reorganizing the supply chain entails agreement codes of practice as well as outlining a typical GI products, established certification schemes together with mechanisms of governance, developing both formal or informal contracts to bring to terms the deportation of intermediate goods along the supply chain, administering the manufacturing process in its stages along the chain, marketing and protecting the product (Rangnekar, 2004).

The final contradictory argument worth noting is that, quality is socially and culturally build thought, which designates from particular practitioners within niche segments as well as markets based on producers' own-driven standards together with expectations that are relative to the technical features of the production process (Ilbery and Kneafsey, 2000). Furthermore apparently firms had adopted a skeptical tendency of defining quality as a measurable object, which could be standardized and connected to localities on the basis of certificatory and legislative measures. According to Rocchi and Gabbi (2013), most problems facing the marketing of wines or agri-food products in the UK 
emanated from the failure to adopt a conventional definition of quality was relevant to the British markets, such as other Italian wines and agri-food products, which confuse the British consumers. 


\section{Sub-objective 3. How Value Chain Governance Works}

According to Sun and Zhang (2009), value chain governance must be able to possess a power and authority affair that drives how finances, material as well as human resources are assigned and worked along the chain to achieve the firms' economic interests. Humphrey and Schmitz (2001), further indicate that, governance must be able to determine the supplier capabilities in terms of what or how a product must be produced and when, how much together with at what price, so within these issues, there are existing relationships that need to be maintained and retained, as well as adopted and adapted constantly to acclimatize to the challenges of the internal and external environmental forces. And, this further grows beyond the domestic platforms. On the other hand, there is an aspect of power relationships or power sharing that mostly relates to the lead firms and members, by which Gereffi, Humphrey and Sturgeon (2003) outlines it as the ability of a firm to drive the management of value chain, and as a result imposing an impact or influence as well as on authority over other firms along the chain. And this can appear from either sector of the value chain network.

According to Gereffi (1994), the intensity of power relationships and their asymmetries are subjected to the nature of the governance structure in the composition of the value chain, in which responsibilities, activities and goals, are ranked and streamed according to the degree of specialty, finance, material and human resources. Often exercised by lead firms, governance ensures the structure under which subordinate firms should operate, even stimulating business relationships between global lead firms and domestic producers. Kaplinsky (2000) further prioritizes the importance of power relations between various actors along the value chain, which regulated to which extend profits are made together with the circulation of uncertainties amongst stakeholders. Additionally, the emphasis is also on how power relations determined the degree to which lead firms are capable of setting as well as imposing guidelines that are targeted at increasing the entry barricades for rivals in order to gain bigger market share and ownership. However, according to Megento (2010), the question still remains as to how to quantify these power relationships or relations while trying to gain authority for administering resources and allocation of value creation.

Humphrey and Schmitz (2002), highlight that access to markets in the developed countries has become rapidly reliant on entering into the global production networks of lead firms (retailers or brand name companies), whereby trading is carried out in a form of business dealings between subsidiaries of transnational companies that is based mostly on transactional relationships and political economy as far as power was concerned. The transnational supermarket chains continue to control whatfood to grow, where, how, and by whom (Konefal, Mascarenhas and Hatanaka, 2005). Key stakeholders offer governance over the production that occurs on a global basis (Kaplinsky, 2004).

Based on Keane (2008) and Kaplinsky's (2014) evidence, the global value chain governance structures can restrict or boost the relevance of fresh business or brand-new developmental beliefs regarding learning through doing, as a result this, there will be a value chain upgrade, which can create opportunities for producers and limitations for others as well as improving the acquisition of production capacities. Furthermore, studies relate to the determinants of value chain governance structures highlight that in market-based governance producers are price takers since production and price settings were done by suppliers without any buyer's concern, while in quasi-hierarchy governance, there is a high level of control due to the buyer's perceived risk of losses fromsupplier competence failures (Trienekens, 2011; and Humphrey and Schmitz, 2004).

\section{Sub-objective 4. Avoiding Bottleneck Situations Along the Supply Chain, as Part of The Value Chain Governance}

Bottleneck situations can occur anywhere in a company's supply chain for various reasons; they can take place in production, distribution, completion and other relevant activities since supply chain's risks are prevailing and critical issues that require to be constantly identified and addressed. This in a 
process occur when input came faster than anticipated or the next step in production could not handle in creating output due to incompetent machinery and production dynamics, this, as a result, cause 
capacity shortages which then affect the firm's competence to mature, making profits to deteriorate (Snow 2013; Castaldi, 2014; and Nexterus, 2016). Therefore, it is very important to identify and fix bottlenecks as soon as possible before they affect the firm's overall revenues, so firms will need to thoroughly understand the following factors:

\section{- Gain visibility and analyze data to find bottlenecks}

The responsible body or lead firm needs to devise means of seeing the processes that occur along the supply chain in order to pick up where bottlenecks took place, machinery or equipment and products, or through captured data if the whole operation was automated from the beginning to the end (Castaldi, 2014).

\section{- Adding automation to eliminate bottlenecks}

Studies indicate (Tripathi, 2015) that the adding of technological-enabled machinery or automation equipment in the production line along the supply chain can reclaim wasteful processes in the distribution center and avoid losing production time around areas of picking, sorting, loading and unloading.

\section{- $\quad$ Downtime can create bottlenecks}

If there is a frequent breakdown of material handling systems, then there can be a downtime, which can cause firms to run at a loss, therefore, opting to organize machinery servicing in terms of maintenance can eradicate that (Castaldi, 2014).

According to Snow (2013), there are situations where bottleneck occur or applicable besides in the production lines and these are regarded as procurement bottlenecks, which involve access to funds, cumbersome processes, and quality matters, and can lower down the line breeding corruption which could bring more ideas about quality assurance. These are the results of the bottleneck that occur outside the core procurement, a major aspect of the supply chain. Furthermore, in network relationships just like any other relations, conflicts do exist, which can affect the flow of activities and all along the supply chain, however, learning as well as managing them sufficiently sustain good relationships, which can somehow avoid bottleneck situations (Gereffi, 1994).

\section{Sub-objective 5. Lessons Learned for Future Research and Possibilities of GIs Applications in South Africa}

The lessons drawn from this summary of relevant literature relate to the analysis of governance mechanisms in the supply chain pertaining the GIs for wine and food products, and other factors that still require further analysis, therefore, providing guidance for future studies of this nature as follows.

Geographical Indications have not been utilized to their utmost best and they need to be supported or accompanied by other mechanisms or strategies for wine and food products, in order to give out their full business potential. Also, firms need to explore whether GIs are the only options or whether there were any other alternative approaches or ways to guarantee wealth through rural economic development besides GIs are too expensive to register and run a GI (Bowen, 2010; Idris, 2003; and Canavari et al, 2017). This scenario will be applicable in addressing the South African agricultural environment in terms of rural development in order to empower SMEs and to determine the right protection mechanisms for other specialty products that are shared amongst various ethnic or cultural groups, such as the case of "Taro" (Amadumbe) a root product that is consumed as potatoes, which is enjoyed and shared amongst the Zulu (AmaZulu) tribe, South African Indian groups and Swati people of South Africa in the Mpumalanga province. One other interesting contention on GIs that 
researchers depicted from other studies regarding the wines and spirits trading between South Africa and the European Union is the changed use of names. Names such as Port and Sherry that South Africa incorporated on its products for some time, which according to TRIPS' legislation is regarded as misleading since the true place origins for these names were "Port" from Portugal and "Sherry" from Spain, and that threaten the country's membership status unless this is rectified. According to Stern (1999), this misleading use of words that denotes the places of origins, emanates from the nittygritty associated with 1930's crayfish trade agreement between South Africa and France in relation to France taking over the crayfish industry in return granting South Africa rights to protect certain appellations of origin hence it refers to its own sparkling wines as Champagne and its red wines as Burgundies. This made South Africa the pioneer in wine production from new world countries to initiate and to identify GIs in wine trading, which then accustomed it to the rights over the use of conditional trademarks.

Moreover, firms must continuously create or reinforce awareness of wine GIs to consumers, because not all of them understand what their agenda dwell upon (Bowen, 2010). Wine and food businesses or products value chain governance' structures, should always be designed and revolved around identifying and satisfying consumer's needs and wants, and understanding the dynamics of the marketing environment of the wine and food industries, because consumers are very smart, in way that they pretty much know what works best for them (Rangnekar, 2004; Rocchi, and Gabbai, 2013; and Tocco, Carmen and Gorton; 2015).

It has been noted that governance structures or mechanisms are generally subjected to the nature of the product, business and industry the firm is into not forgetting the legalities, and that can be affected furthermore by other uncontrolled macro-environmental factors that firms need to abide by. Most importantly value chain governance structures have a great potential to restrict or create opportunities for new business ideas at both local and global level (Keane, 2008; and Kaplinsky, 2014). It can be worth knowing how their different sequences can work in emerging market.

Another major aspect for consideration is the issue of "trust", which seems to be the dependable factor within the supply chain's members, which also signifies value creation, not being cheap at all and does not even come overnight (Vieira and Traill, 2008). According to Hofstede et al (2010), this phenomenon is a complicated issue since it relies on one's gut feelings about somebody or familiarity towards them, which will be based on believing in their capabilities, generosities, honesty and intelligence. Moreover, as a sensitive cultural issue, trust depends on how it is built and earned, which can transverse from country or country developing reliable business relations amongst partners from various cultures. Now, it will be interesting to find out as to how to measure and rely on it, because it is basically everything governance (Raynaud, 2002; and Rangnekar, 2004). This also works for hand in hand with the notion of how "power" in terms sharing or relations by both lead firms and chain members, as in how it works as well as how it is shared to as far as in transnational relationship situations (Gereffi, Humphrey and Sturgeon, 2003).

Finally, it has been noted that the bottleneck situations in the supply chains of wine and food industry were caused by various reasons that relate to the malfunctioning management of all activities including members and the supply chain risks in general, which require constant attention and technological mechanisms to ensure the elimination of these situations as well as having to be able to have operational records in a form of database that will be fed by these automated facilities to ease tracking in future occurrences (Snow 2013; Castaldi, 2014; and Nexterus, 2016).

\section{DISCUSSION AND CONCLUSION}

This study uses wine and food products, specifically GI ones, since they are quality certified and can be traced easily, to study how value chains function in terms of governance. However, according to Caswell, (1991); and Bäckstrand (2003), the notion of differentiation, which seems to be one of 
the dominant strategic responses to demand for food safety, is actually the major challenge, which is 
subjected to the issue of trust in agri-food systems and can possibly create barriers to entry. Therefore, the study reviews and summarizes previous case studies that relates to the supply chaingovernance structures and mechanisms in Italy, UK specifically England and Wales, and other surrounding developed countries. This is based on several sub-objectives that have been outlined earlier, which are holistically analyzing the diverse aspects of value chain governance and its types, GIs and the wine and food industries in these regions.

Findings indicate that GIs are interesting concepts that further need to be explored, since they are not easy and cheap to start let alone to run, and in running them they require enormous help or boost from other strategies such as marketing. In addition, the economic shared benefit amongst members relies on fixed prices or sometimes fluctuations, which will be determined by market conditions, demand and supply, product type, transportation and packaging (Rosati, 2015).

Furthermore, as for value chain governance, the structure and type will be determined or dependent on the type of a product, business and the industry in which the firm operates, plus law issues. Most importantly, power sharing and trust factors are found to be very crucial and interesting as they are the main drivers of everything in this context and more about these concepts, whereby firms set up cheap business strategies in the industry that force them to be inclined to vague future business outcomes.

Some studies conversely, indicate that there is a new revolution of wine and food actors who are against the motion of being regulated, who feel all these management regulations are just waste of public money (Devaney, 2016). The findings also, indicate that customers together with their opinions must always be considered and put first in any business decision since they are the main reason why firm survive.

The study, therefore, concludes that products that are protected under their designations of origins can help to solve this issue of traceability, safety and other health concerns, through proper management, these products have the power to determine the structure of their governance along the chains, through the incorporations of other strategies.

Moreover, there must be a development of adaptive and conforming governance structures as well as the regulatory system in place that can withstand any risks arising in the supply chains in order to defeat the existing and coming ones.

On the basis of this study researchers believe that when it is about GIs' governance, every consortium member must clearly understand that GI products are not just like any other products, but rather specialty products from a particular place whose qualities can never be replaced or compromised. This is because uniqueness is the strength of a GI product.

In addition, as protective as GIs are in terms of developing a product, they can also be incorporated and used as value-enhancement tools in situations such as place marketing. The problem is to find out as to how investment, burden and enjoyment of gain could be distributed amongstmembers.

Therefore, this means that every consortium member, policy makers and governments must be encouraged to involve themselves in effective promotional activities that will be aimed at creating awareness and education about these premium products to the consumers and any other stakeholder in both the European Union and emerging markets. This will stimulate the demand for the consumption of certified agri-food and wine products in order to address the prevailing concerns about food safety and traceability in the global supply. Again, this will also help in contributing towards the creation of local economy, and the sharing of costs and gains amongst the GIs’ consortium members.

Thus, further investigations are proposed to determine governance sequences using GIs in multi- 
cultural and ethnicity countries, whereby countries such as South Africa can create their own GIs systems as well as appropriate mechanism of governing them.

This will not only increase their global competitiveness by enhancing the campaigning initiatives such as Proudly South African, but will even offer other neighboring countries protection opportunities. 


\section{REFERENCES}

Addor, F., \& Grazioli, A. (2002). Geographical Indications Beyond Wines and Spirits. A Roadmap for a Better Protection for Geographical Indications in WTO/TRIPS Agreement. The Journal of World Intellectual Property, 5(6), 865-897. doi:10.1111/j.1747-1796.2002.tb00185.x

Agostino, M., \& Trivieri, F. (2014). Geographical Indication and Wine Exports. An Empirical Investigation Considering the Major European Producers. Food Policy, 46, 22-36. doi:10.1016/j.foodpol.2014.02.002

Albisu, L., M. (2002). Work Programme 2: Link Between Origin Labelled Products and Local Production Systems, Supply Chain Analysis (Final Report). European Commission.

Bäckstrand, K. (2003). Civic Science for Sustainability: Reframing the Role of Experts. Policy-Makers and Citizens in Environmental Governance. Global Environmental Politics, 3(4), 24-41. doi:10.1162/152638003322757916

Balwin, C., \& Clark, K. (2001). Design Rules. Cambridge, MA: MIT Press.

Banga, R. (2013). Measuring Value in Global Value Chains. Regional Value Chains: Background Paper No. RVC-8. UNCTAD. Retrieved9/06/2016 from http://unctad.org/en/PublicationsLibrary/ecidc2013misc1_bp8.pdf

Barnes, A., Bassot, B., \& Chant, A. (2011). An Introduction to Career Learning and Development. In Perspectives, Practices and Possibilities (pp. 11-19). Master e-book.

Barreiro-Hurle, J., Colombo, S., \& Cantos-Villar, E. (2008). Is there a Market for Functional Wines? Consumer Preferences and Willingness to Pay for Resveratrol-enriched Red Wine. Food Quality and Preference, 19(4), 360-371. doi:10.1016/j.foodqual.2007.11.004

Battaglene, T. 2011. Overview of the International Framework of International Organizations and Agreements. In Proceedings of the Importance of International Organizations in Wine Regulation. Seminar on Key Issues in Wine Regulation (pp. 18-19).

Bitzer, V., Obi, A., \& Ndou, P.(2016). Keeping up the Rising Quality Demands? New Institutional Arrangements, Updating and Market Access in the South African Critics Industry.

Bowen, S. (2010). Development from Within? The Potential for Geographical Indications in the Global South. The Journal of World Intellectual Property, 13(2), 231-251. doi:10.1111/j.1747-1796.2009.00361.x

Bramley, C., \& Kirsten, J. (2007). The Economics of Geographical Indications: Toward a Conceptual Framework for Geographical Indication Research in Developing Countries (Contributed Paper). In International Roundtable on the Economics of Intellectual Property Rights, WIPO, Geneva, November26-27.

Canavari, M., Hawkins-Mofokeng, R. H., de Souza, A. L., Hartmann, P. V. P., Radić, I., \& Wongprawmas, R. (2017). Consumer Preferences Marketing Problems and Opportunities for Non-EU-based GIs: Experiences for Brazil, Serbia and Thailand. In Geographical Indications as Cultural Property. Taste, Power, Tradition (pp. 86-102).

Castaldi, C. (2014). Eliminating Bottlenecks in the Supply Chain. Retrieved 29/06/2016 from www.apparel_edgl. com/news/Eliminating-Bottlenecks-in-the-Supply-Chains95472

Caswell, J. A. (1991). Economics of Food Safety. Elsevier Science Publishing Co., Inc. Retrieved 25/08/2016 from https://books.google.it/books?id=ETWYBwAAQBAJ\&pg=PA274\&lpg=PA274\&dq=differentiation+str ategy+food+safety\&source=bl\&ots=FSezgzcpKd\&sig=sfLG7e0wh1z7Alt6RO-RkWYZAJI\&hl=it\&sa=X\&v ed=0ahUKEwilro3ztNzOAhVIxRQKHU3ODhgQ6AEIITAA\#v=onepage\&q=differentiation\%20strategy\%20 food\%20safety\&f=false

CBI Trends: Wine in the United Kingdom. Market Intelligence. (2016). Retrieved 17/06/2016 from http://www. cbi.eu/disclaimer

Cimino, M. G. A., \& Marcelloni, F. 2010. Chapter 20: Enabling Traceability in the Wine Supply Chain. Retrieved 16/06/2016 from http://www.iet.unipi.it/m.cimino/publications/cimino_pub27.pdf

Climent-Lopez, E., Sanchez-Hernandez, J. L., Canto-Fresno, C., Alonso-Santos, J. L., Ramirez-Garcia, S., RoderoGonzalez, V., \& Ruiz-Budria, E. (2014). Measuring Quality Conventions in the Food Industry: Applications to the Wine Sector in Spain. Geoforum, 56, 148-160. doi:10.1016/j.geoforum.2014.07.004 
Consoli, D., \& Patrucco, P. P.(2007). Innovation Platforms and the Governance of Knowledge: Evidence from Italy and the UK. Economics of Innovation and New Technology, 17(7-8), 699-716. doi:10.1080/10438590701785694

Craven, E., \& Mather, C. (2002). Geographical Indications and the South Africa-European Union Free Trade Agreement. Wiley Online Library. Retrieved 23/07/2016 from www.onlinelibrary.wiley.com/doi/10.1111/14754762.00034/abstract

Devaney, L. (2016). Good Governance? Perceptions of Accountability Transparency and Effectiveness in Irish Food Risk Governance. Food Policy, 62, 1-10. doi:10.1016/j.foodpol.2016.04.003

ERRT. (2016). Good Practices in the Food Supply Chain. European Retail Round Table, Bringing Together Europe's Leading Retailers. Retrieved 16/07/2016 from www.errt.org/issues/good-practices-food-supply-chain

Fagundes, P. M., Padilha, A. C. M., Sluszz, T., \& Padula, A. D. (2012). Geographical Indication as a Market Orientation Strategy: An Analysis of Producers of High-Quality Wines in Southern Brazil. Database Marketing and Customer Strategy Management, 19(3), 163-178. doi:10.1057/dbm.2012.18

Fearne, A. 2009. Sustainable Food and Wine Value Chains. Thinkers in Residence. Available. Retrieved 15/06/2016 from www.slideshare.net/jlomman/sustainable-food-amp-wine-value-chains

Fung, V. (2011). Global Supply Chains - Past Developments, Emerging Trends. Retrieved 15/072016 from http://www.fungglobalinstitute.org/publications/speeches/global-supply-chains--past-developments-emergingtrends-193

Gellynck, X., \& Molnar, A. (2009). Chain Governance Structures: The European Traditional Food Sector. British Food Journal, 111(8), 762-775. doi:10.1108/00070700910980900

Gereffi, G. (1994). The Organization of Buyer-driven Global Commodity Chains: How U.S. Retailers Shape Overseas Production Networks. In G. Gereffi \& M. Korzeniewicz (Eds.), Commodity Chains and Global Capitalism. Westport: Praeger.

Gereffi, G., \& Fernandez-Stark, K. (2011). Global Value Chain Analysis: A Primer. Retrieved 23/06/2016 from http://www.cggc.duke.edu/pdfs/2011-05-31_GVC_analysis_a_primer.pdf

Gereffi, G., Humphrey, J., \& Sturgeon, T. (2003). The Governance of Global Value Chains. Forthcoming in Review of International Political Economy.

Gereffi, G., Humphrey, J., \& Sturgeon, T. (2005). The Governance of Global Value Chains. Review of International Political Economy, 12(1), 78-104. doi:10.1080/09692290500049805

Giovannucci, D. (2007). Geographical Indications - Approaches and Value. Retrieved 17/08/2016 from www. ico.org/event_pdfs/gi/presentations/Giovannuccitxt.pdf

Goldenberg, S. (2016). Half of All US Food Produce is Thrown Away, New Research Suggests. Food Waste. The Guardian. Retrieved 15/07/2016 from https://www.theguardian.com/environment/2016/jul/13/us-foodwaste-ugly-fruit-vegetables-perfect

Hammervoll, T. (2011). Governance of Value Creation in Supply Chain Relationships. Supply Chain Forum. International Journal (Toronto, Ont.), 12(2).

Humphrey, J., \& Schmitz, H. (2001). Governance in Global Value Chains. PDS Bulletin, 32(3). Retrieved 31/05/2016 from www.ids.ac.uk/files/humphrey_schmitz_32_3.pdf

Humphrey, J., \& Schmitz, H. (2002). Developing Country Firms in the World Economy: Governance and Upgrading in Global Value Chains: INEF Report. Retrieved 29/06/2016 from www.citeseerx.ist.psu.edu/viewdoc/ download?doi=10.1.1.557.1063\&rep=1\&type=pdf

ICE. (2010). Raccolta delle Documentazioni Necessarie per I'esportazione de Vino. Verona.

Idris, K. 2003. Intellectual Property: A Power Tool for Economic Growth. Overview: WIPO. Retrieved 29/06/2016 from http://www.wipo.int/edocs/pubdocs/en/intproperty/888/wipo_pub_888_1.pdf

Ilbery, B., \& Kneafsey, M. (2000). Producer Constructions of Quality in Regional Specialty Food Production: A Case Study from South West England. Journal of Rural Studies, 16(2), 217-230. doi:10.1016/S07430167(99)00041-8 
Kaplinsky, R. 2000. Spreading the Gains from Globalization: What Can be Learned From Value Chain Analysis? (IDS Working Paper 110).

Kaplinsky, R. (2004). Spreading the Gains from Globalization: What Can be Learned from Value-Chain Analysis? Problems of Economic Transition, 47(2), 74-115.

Keane, J. (2008). A “New Approach” to Global Value Chain Analysis. Working Paper 293. Retrieved 29/06/2016 from www.odi.org/sites/odi.org.uk/files/odi-assets/publications-opinion-files/2732.pdf

Konefal, J., Mascarenhas, M., \& Hatanaka, M. (2005). Governance in the Global Agro-Food System: Backlighting the Role of Transnational Supermarket Chains. Agriculture and Human Values, 22(3), 291-302. doi:10.1007/ s10460-005-6046-0

Lee, J., Gereffi, G., \& Beauvais, J. (2012). Global Value Chains and Agrifood Standards: Challenges and Possibilities for Smallholders in Developing Countries. Retrieved 15/06/2016 from www.pnas.org/cgi/ doi/10.1073/pnas.09137141908

Mariani, A., Pomarici, E., \& Boatto, V.(2012). The International Wine Trade: Recent Trends and Critical Issues. Wine Economics and Policy, 1(1), 24-40. doi:10.1016/j.wep.2012.10.001

Megento, T. L. 2010. Inter-firm Relationships and Governance Structures. A Study of the Ethiopian Leather and Leather Products Industry Value Chain. Retrieved 29/06/2006 from https://books.google.it/books?id=tap 8_5FILgwC\&printsec=frontcover\&dq=Interfirm+Relationships+and+Governance+Structures.\&hl=it\&sa= X\&redir_esc=y\#v=onepage\&q=Interfirm\%20Relationships\%20and\%20Governance\%20Structures.\&f=false

Menkhoff, T. (1992). Xinyong or How to Trust Trust? Chinese Non-Contractual Business Relations and Social Structure: The Singapore Case. Internationales Asian Forum, 23(1-2), 261-88.

Microlinks. (2016). Value chain governance overview. Retrieved 25/05/2016 from https://www.microlinks.org/ good-practice-center/value-chain-wiki/value-chain-governance-overview

Moser, R., Raffaelli, R., \& Thilmany-McFadden, D. 2011. Consumer Preferences for Fruit and Vegetables with Credence-Based Attributes: A Review. IFAMA: International Food and Agribusiness Management Review, 14(2).

Nexterus. (2016). How Can You Avoid Bottlenecks in Your Supply Chain? All Things Nexterus: Our Take. Retrieved 29/06/2016 from www.nexterus.com/add-things-nexterus/our-take/how-to-avoid-supply-chainbottlenecks/

Oronzo, L. N., D., \& Partners. 2013. The Italian Wine Industry. Incoporate in Italy. Available Retrieved 25/05/2016 fromhttps://www.incorporateinitaly.wordpress.com/2013/09/17/the-italian-wine-industry/

Overton, J., \& Heitger, J. (2008). Maps, Markets and Merlot: The Marketing of an Antipodean Wine Appellation. Journal of Rural Studies, 24(4), 440-449. doi:10.1016/j.jrurstud.2008.01.002

Petti, L., Raggi, A., De Camillis, C., Matteucci, P., Sàra, B., \& Pagliuca, G. 2006. Life Cycle Approach in an Organic Wine-making firm: An Italian Case-Study. In Proceedings of 5th Australian Conference on LCA, Melbourne, Australia, November 22-24.

Porter, M. E. (1985). Porter's Generic Competitive Strategies (way of competing). In Competitive Advantage (Ch. 1, pp. 11-15). New York: The Free Press. Retrieved 9/06/2016 from http://www.ifm.eng.cam.ac.uk/research/ dstools/porters-generic-competitive-strategies/

Rangnekar, D. (2004). The Social-Economics of Geographical Indications. Intellectual Property Rights and Sustainable Development: UNCTAD-ICTSD Project on IPRs and Sustainable Development. Retrieved 29/06/2016 from www.ictsd.org/sites/default/files/research/2008/07/a.pdf

Raynaud, E., Sauvee, L., \& Valceschini, E. (2002). Quality Enforcement Mechanisms and the Governance of Supply Chains in the European Agro-food Sector. In Proceedings of the $6^{\text {th }}$ Annual Conference, International Society for New Institutional Economics, "Institutions and Performance” (pp. 27-29). MIT.

Ritchie, C. (2011). Young adult interaction with wine in the UK. International Journal of Contemporary Hospitality Management, 23(1), 99-114. doi:10.1108/09596111111101698

Robinson, J. (2016). United Kingdom: Weekly Newsletter. Retrieved 25/05/2016 from www.jancisrobinson.com 
Rocchi, B., \& Gabbai, M. (2013). Territorial Identity As a Competitive Advantage in Wine Marketing: A Case Study. Journal of Wine Research, 24(4), 219-310. doi:10.1080/09571264.2013.837382

Rosa, D. M. (2015). The Role of Geographical Indication in Supporting Food Safety: A not Taken for Granted Nexus. Italian Journal of Food Safety, 4(4). PMID:27800417

Rosati, M. (2015). Geographical Indications. A Different Way to Access The Global Food Market. Qualivita, Innovation Norway. Retrieved 16/08/2016 from www.qualivita.it/wp-content/uploads/2015/11/20151119_ PresentazioneNorvegia-ENG.pdf

Rosati, M. (2016). The Future of the Consortiums of Origin Italy (Conference). Retrieved 16/06/2016 from http://www.teatronaturale.it/tracce/italia/22957-il-futuro-dei-consorzi-di-tutela-delle-denominazioni-di-originel-italia-ci-scommette.htm

Siddle, R. (2015). WSTA’s Call Time on Duty Campaign Wins Major PR. Harpers.co.uk. Retrieved 16/06/2016 from http://www.harpers.co.uk/news/wstas-call-time-on-duty-campaign-winsmajorpraward/514524.article?utm_ source=RSS_Feed\&utm_medium=RSS\&utm_campaign=rss

Skilton, P. F., \& Wu, Z. (2013). Governance regimes for protected geographical indicators impacts on food marketing systems. Journal of Macromarketing, 33(2), 144-159. doi:10.1177/0276146712473116

Skuras, D., \& Vakrou, A. (2002). Consumers' Willingness To Pay for Origin Labeled Wine: A Greek Case Study. British Food Journal, 104(11), 898-912. doi:10.1108/00070700210454622

Smithers, R. (2015). How English Wine Went From a Joke to Sales of 6m Bottles a Year. The Guardian. Retrieved 20/07/2016 from https://www.theguardian.com/sustainable-business/2015/dec/16/english-wineindustry-vineyards-sales-6m-bottles

Snow, J. (2013). Addressing Procurement Bottlenecks: A Review of Procurement Bottlenecks in Public Sector Medicine Supply Chains and Practical Approaches Taken to Resolve Them. USAID: Deliver Project. Retrieved 29/06/2016 from www.deliver.jsi.com/dlvr_content/resources/allpubs/policypapers/AddrProcBottl.pdf

Stasi, A., Nardone, G., Viscecchia, R., \& Seccia, A. (2011). Italian Wine Demand and Differentiation Effect of Geographical Indications. International Journal of Wine Business Research, 23(1), 49-61. doi:10.1108/17511061111121407

Stern, A. (1999). The Protection of Geographical Indications in South Africa. In Symposium on The International Protection of Geographical Indications. Retrieved 23/07/2016 from http://www.wipo.int/mdocsarchives/ WIPO_GEO_CPT_99/WIPO_GEO_CPT_99_3a_E.pdf

Sun, Z., \& Zhang, G. (2009). Beyond Typologies of Global Value Chain Governance: The Accumulation of Technological Capabilities. International Journal of Business and Management, 4(1), 32-37. doi:10.5539/ ijbm.v4n1p32

The International Organization of Vine and Wine (OIV). (2016). Top Fifteen Wine-Producing Countries. Italian Wine Central.

Tocco, B., Carmen, H., \& Gorton, M. (2015). Competitiveness of the EU Agri-food Sector: A Synthesis of Findings from the COMPLETE Project (COMPLETE Working Paper). International Comparison of Product Supply Chains in the Agro-food Sector, 16.

Trienekens, J. H. (2011). Agricultural Value Chains in Developing Countries, A Framework for Analysis. The International Food and Agribusiness Management Review, 14(2).

Tripathi, S. (2015). Supply Chain Job-Bottlenecks in FMCG Market. Retrieved 25/08/2016 from https://www. linkedin.com/pulse/supply-chain-job-bottlenecks-fmcg-market-cmilt-urgent-need-of-job

Vincent, C., McLeish, M., \& Soemali, A. (2014). From Farm to Plate, or Farm to Waste? PWC Indonesia. Retrieved 17/07/2016 fromhttp://www.pwc.com/id/en/media-centre/pwc-in-news/2014/english/from-farm-toplate-or-farm-to-waste.html

Williamson, O. E. (1991). Comparative Economic Organization: The Analysis of Discrete Structural Alternatives. Administrative Science Quarterly, 36(2), 269-296. doi:10.2307/2393356 
Wilson, J. (2016). United Kingdom: UK Wine Market Report 2016. USDA Foreign Agricultural Service. Global Agricultural Information Network.

Wine Institute. (2010). International Trade Barriers Report for U. Wines-2010. Winemakers' Federation of Australia. 2010. Submission on the Transpacific Partnership Agreement Submission to DFAT.

Wittwer, G., Berger, N., \& Anderson, K. (2003). A Model of the World's Wine Markets. Economic Modelling, 20(3), 487-506. doi:10.1016/S0264-9993(01)00095-5

Woodford, C. (2015). Barcodes and Barcode Scanners. Explainthatstuff. Retrieved 16/07/2016 from www. explainthatstuff.com/barcodesscanners.html

WSTA. (2014). The Wine and Spirits Trade Association. Market Overview: UK Wine and Spirits. Retrieved 17/06/2016 from www.wsta.co.uk

Yin, R. K. (2014). Case Study Research. Design and Methods (5th ed.). Sage.

Raymond H. Hawkins-Mofokeng, PhD graduate in Agricultural, Environmental, and Food Science and Technology \& ISA research fellow, University of Bologna Italy, Marketing management Lecturer, Durban University of Technology, South Africa, Interdisciplinary \& Hip-Hop scholar, Strategist \& Entrepreneur, Father \& Husband, a Humble-friend, South African citizen.

Maurizio Canavari holds a Laurea degree in Agricultural Sciences (Bologna, 1990) and got a Doctoral Degree in Appraisal and Land Economics (Padua, 1997). Researcher at the Alma Mater Studiorum University of Bologna since April 1998 and Associate Professor since October 2005. Current research interests include agri-food marketing and marketing research, with specific topics regarding quality food specialties, organic food, e-commerce and wine business. ORCID: http://orcid.org/0000-0003-0573-7880.

Martin Hingley was born and schooled in Lincoln. He is Professor of Strategic Marketing at University of Lincoln (Lincoln International Business School). Before that he was Reader in Marketing at Harper Adams University in Shropshire. His research interests are in marketing and supply chain management. His specialism is in business network relationships, having published and presented extensively on the management of power-dependency in retail supply. He has published widely, including four joint edited books in the Food and Agricultural Marketing series recently published by Gower-Routledge. Martin has wide-ranging business experience in the international food industry and spent some time in provision of market and business analysis and industry based training with the Institute of Grocery Distribution (IGD), UK. He previously held a three-year fellowship with Tesco PIc. 